\title{
Familial Occurrence of Congenital Malformations and Ring Chromosome (46,XX,Cr)
}

\author{
G. GACS, D. SCHULER, and M. SELLYEI \\ From Second Department of Paediatrics, University Medical School and Department of Pathology, Robert Károly \\ Hospital, Budapest, Hungary
}

A ring chromosome in group $\mathrm{C}$ has been described only rarely (Atkins et al., 1960; Turner et al., 1962; Butler, France, and Jacoby, 1967). We here report a family where there have been numerous miscarriages and congenital malformations, and in one member of which a ring chromosome of the $\mathrm{C}$ group was detected.

\section{Case Reports}

The pedigree (Fig. 1) shows that in the first and second generations no aberration was found; it is only in the third generation that miscarriages, prematurity, and congenital malformations appear.

II.3. A healthy female was pregnant nine times but has only one healthy living child; two of her children had congenital malformations, one of these was stillborn, the other died a few days after birth. The other 6 pregnancies resulted in miscarriages.

III.9. Stillborn at full-term. Apart from congenital heart disease (agenesis of pulmonary valve), no other abnormality was found.

III.13. Premature $(2400$ g.). Died after 16 days. Necropsy. revealed jaundice, congenital heart disease (atrial and ventricular septal defect, aortic hypoplasia), and polycystic kidney.

II.4. The mother of the proposita is healthy and has three normal boys. The third pregnancy resulted in twins (III.16, III.17).

II.5. The father of the proposita. No congenital malformation was found in him or in his family.

III.16. The 2-year-old girl (Fig. 2), birthweight 2800 g., height $82 \mathrm{~cm}$., weight $8600 \mathrm{~g}$., was microcephalic, with head laterally flattened, and protruding beaklike frontal bone. Slanting eyes, hypertelorism, epicanthus, horizontal nystagmus discoloured papillae. Ears low-set and dissimilar. Palate gothic, teeth regular, 6/6. Small, wide-apart nipples. Labia majora hypoplastic.

Received 10 November 1969.
On both sides between toes II and III there was partial syndactyly. The skin was poorly pigmented. Psychomotor development was delayed and mental development was greatly retarded. The urinary excretion of amino acids was normal on thin layer chromatography.

III.17. This twin sister of III.16, with birthweight $3000 \mathrm{~g}$., died at the age of 2 months. The right side of face was normal, left side was hypotrophic with the following malformations: cleft lip, cleft palate, dysplasia of the mandible, microphthalmia, no external auditory canal; in place of the auricle there was a small bud of skin. There was a double thumb on the right side.

II.6. A healthy female; all her four pregnancies ended in miscarriages.

\section{Cytogenetic Studies}

The chromosome studies were performed on peripheral leucocyte culture using Moorhead's slightly modified method (Moorhead et al., 1960; Schuler, 1965). In III.16 (Fig. 3, Table I) most of the cells had a $46, \mathrm{XX}, \mathrm{Cr}$ chromosomal constitution. In the cells containing 45 chromosomes the ring chromosome was

TABLE I

CHROMOSOME COUNTS IN MEMBERS OF FAMILY

\begin{tabular}{c|c|c|c|c|c|c}
\hline $\begin{array}{c}\text { Case } \\
\text { No. }\end{array}$ & $\begin{array}{c}\text { No. of } \\
\text { Cells } \\
\text { Counted }\end{array}$ & $45, \mathrm{Cr}$ & 45 & $46, \mathrm{XX}, \mathrm{Cr}$ & 46 & 47 \\
\hline III.16 & 80 & 3 & 5 & 70 & 2 & \\
III.3 & 31 & 1 & 3 & 24 & 3 & \\
II.4 & 20 & & 3 & 34 & 34 & 1 \\
II.5 & 26 & & 2 & & 18 & \\
II.6 & 20 & & 24 & 1 \\
\hline
\end{tabular}

TABLE II

NUMERICAL DATA OF AUTORADIOGRAPHY

\begin{tabular}{c|c|c|c|c}
\hline & $\begin{array}{c}\text { Cells } \\
\text { Scored }\end{array}$ & $\begin{array}{c}\text { Labelled } \\
\text { Cells }\end{array}$ & $\begin{array}{c}\text { Late } \\
\text { Replicating } \\
\mathbf{X}\end{array}$ & $\begin{array}{c}\text { Labelling } \\
\text { Over Ring } \\
\text { Chromosome }\end{array}$ \\
\hline No. of cells & 155 & 73 & 19 & 25 \\
\hline
\end{tabular}




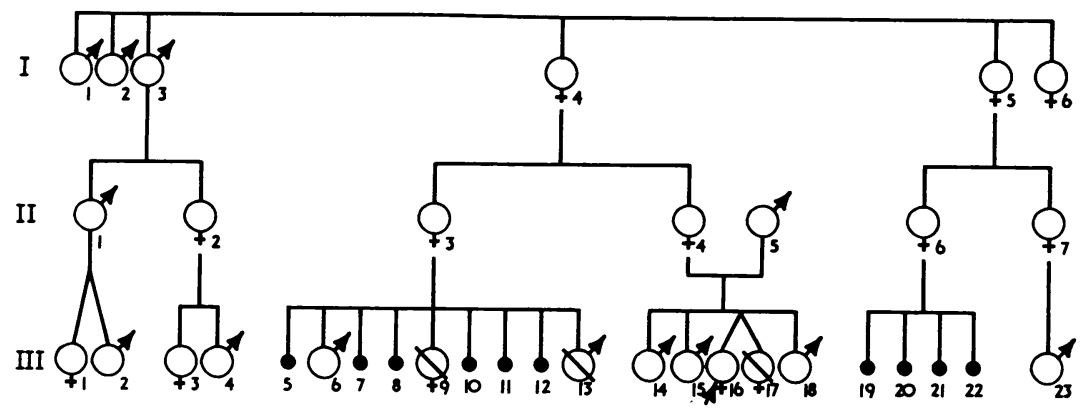

ONormal phenotype QCongenital malformations;died Proposito - Miscarriage

Fig. 1. Pedigree of the family.

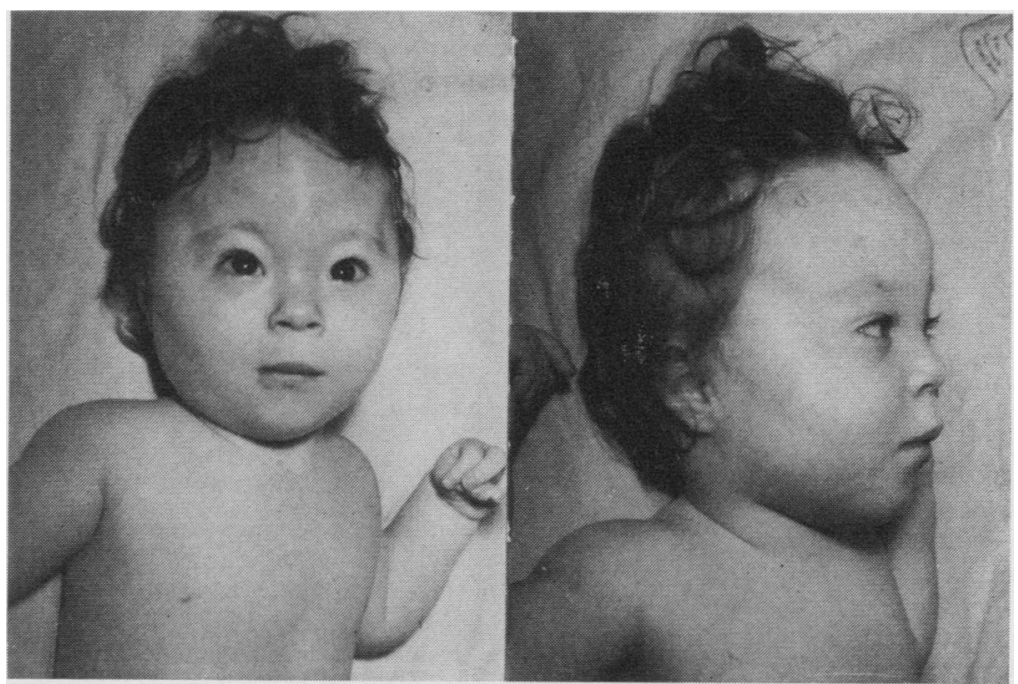

Fig. 2. Photograph of proposita.

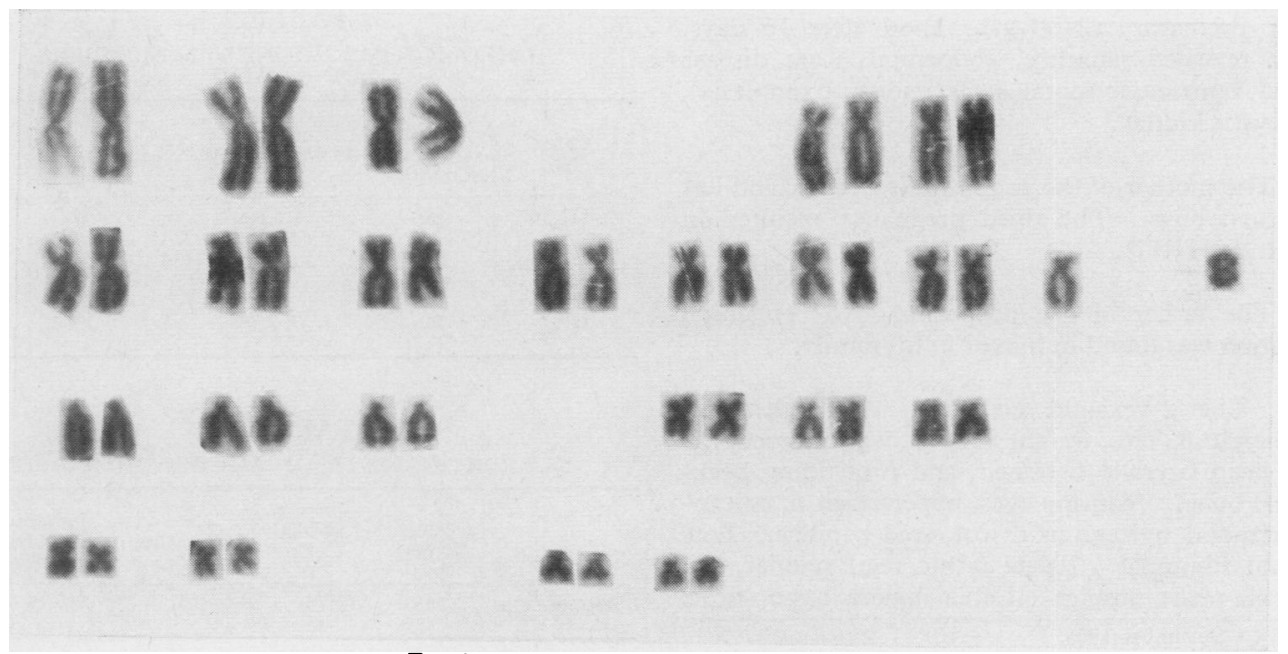

FIG. 3. Karyotype of proposita $(46, \mathrm{XX}, \mathrm{Cr})$. 


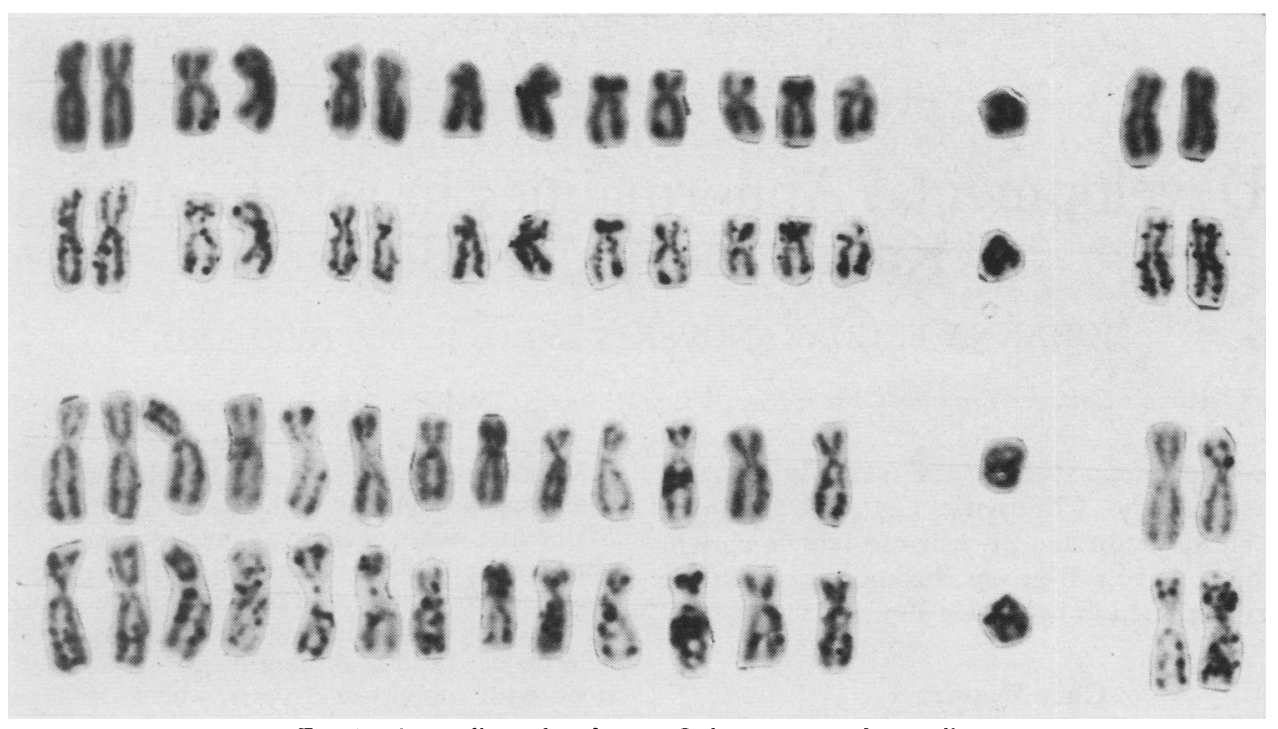

Fig. 4. Autoradiography of group C chromosomes of two cells.

lacking. The form and the size of the chromosome varied, and some of the cells contained two rings. Autoradiography showed that the ring chromosome was not the late replicating one (Table II, Fig. 4).

Buccal smear revealed positive sex chromatin. II.3, II.4, II.5, and II.6 were also examined cytogenetically, but no chromosomal aberration was found.

\section{Discussion}

A 2-year-old girl is described with multiple congenital malformations in whom most of the cultured peripheral blood cells contained a ring chromosome. As regards its size and the arrangement of other normal chromosomes, it belongs to the longer members of group C. Considering the sex chromatin positivity, the symptoms, and the autoradiography, the possibility of its development from the $\mathrm{X}$ chromosome can be excluded.

The clinical picture in other cases of a ring $\mathrm{C}$ chromosome differed from ours and from each other. Though the first case of Atkins et al. shows some similarities to the patient described here (lowset ears, epicanthus, gothic palate, nystagmus, mental retardation), we do not think that the presence of these symptoms would be sufficient to assume that the ring chromosome had originated in both cases from one and the same member of group C. The symptoms in our case were also different from those that have been presented up to now in connexion with other aberrations of chromosomes in the $\mathrm{C}$ group. Since no chromosomal aberrations were found in other members of the family, we cannot explain the great number of congenital malformations and miscarriages.

\section{Summary}

An infant is described with multiple congenital malformations who was shown to havea ring chromosome in group C. In the family there have been numerous cases of congenital malformations and miscarriages. The co-twin of the proposita was also affected. In the healthy members of the family who were examined, no chromosomal aberration was found.

\section{REFERENCES}

Atkins, L., Pant, S. S., Hazard, G. W., and Ouellette, E. M. (1960). Two cases with a C-group ring autosome. Annals of Human Genetics, 30, 1-5.

Butler, L. J., France, N. E., and Jacoby, N. M. (1967). An infant with multiple congenital anomalies and a ring chromosome in group C (X-6-12). Fournal of Medical Genetics, 4, 295-298.

Moorhead, P. S., Nowell, P. C., Mellmann, W. J., Battips, D. M., and Hungerford, D. A. (1960). Chromosome preparations of leukocytes cultured from human peripheral blood. Experimental Cell Research, 20, 613-616.

Schuler, D. (1965). Újabb módszerek az emberi chromosoma vizsgálatára. (In Hungarian.) Orvosi Hetilap, 106, 2366-2367.

Turner, B., Jennings, A. N., den Dulk, G. M., and Stapleton, T. (1962). A self-perpetuating ring chromosome. Medical fournal of Australia, 2, 56-58. 